\title{
The Effect Of POGIL Assisted With Mind Mapping Toward The Science Learning Outcomes
}

\author{
Desak Putu Parmitia ${ }^{\text {I Gede Margunayasa }}{ }^{a}$ \\ ${ }^{a}$ Universitas Pendidikan Ganesha, Udayana Street, Singaraja Bali, Indonesia \\ Corresponding e-mail: dskpt_parmiti@yahoo.co.id
}

\begin{abstract}
The aim of this study was to determine the effect of POGIL assisted with mind mapping toward the science learning outcomes. The type of this study was quasi experimental research with non equivalent design posttest only control group design. The population of this research was the students of grade 5 of primary school in cluster II of Banjar district in Buleleng regency. The sample of this study was the students of grade 5 of SDN 2 Tigawasa, SDN 3 Dencarik, and SDN 3 Tigawasa. The data were collected by using the learning achievement test. The analysis technique used was anova. The result of the study showed that there was a significant effect of POGIL assisted with mind mapping toward the science learning outcomes $(F=27.13$ and significance $<0.05)$. The mean of science learning outcomes for the student who were taught by POGIL assisted with mind mapping was 25.25 more than the student who were taught by POGIL was 24.36 more than the students who were taught by conventional method was 18.16. Thus, there was a significant effect of POGIL assisted with mind mapping toward the science learning outcomes.
\end{abstract}

Keywords: POGIL, mind mapping, science learning outcomes

\section{$1 \quad$ INTRODUCTION}

In the era of globalization every individual is required to prepare qualified human resources, especially in the field of Science and Technology (Science and Technology). Qualified human resources can be prepared through adequate education. This is in accordance with the opinion of Wiratma [1], "Education can be used as a means to deliver qualified human resources."

Viewing the importance of the role of education to the quality of human resources, the government made various efforts to improve the quality of education. The effort that was made by the government has not produced optimal results in improving education in Indonesia. Indonesia's education condition is currently in an emergency condition [2]. Based on the mapping of education on Mathematics and Science subjects from Trends in International Mathematics and Science Studies (TIMSS) from 2011, Indonesia ranks 40th out of 42 countries. Similarly, studies conducted by the Program for International Student Assessment (PISA) to measure students' knowledge on the three basic competencies of reading, mathematics and science in 2016 achievement of PISA Indonesia slightly increased but the achievement is still below the average countries Organization for Economic Cooperation and Development [3]. Based on the
PISA and TIMSS studies, it is necessary to improve the quality of science education in Indonesia.

IPA is one of the main subjects in the education curriculum in Indonesia, including in elementary school [4]. In teaching science an educator must know in advance the nature of the IPA itself. Science has three components: scientific products, scientific processes, and scientific attitudes [5]. Therefore, in science learning must be contained these three components. In science lessons in elementary schools should be done simple investigations based process and not a recitation of a collection of IPA concepts in order for science learning to cover the three components of IPA. Through simple inquiry activities students can build their own knowledge in their minds. This is in accordance with the theory of constructivism which considers that to be able to understand the concept of IPA, the activeness of students to build their own knowledge is needed [6].

Based on the facts during interviews, observations, and documentary studies on January 11, 2017 to January 12, 2017, the following results were obtained. Based on the results of interviews with science subjects teachers, obtained information that science subjects in Gugus II Banjar District have low learning outcomes. The low learning outcomes of students are influenced by the lack of teacher knowledge about the student centered learning model. Most teachers assume that the lecture method 
is the most practical, easy, and efficient method of learning. The teacher assumes that the student has mastered what kind of lesson that has mastered by the teacher.

Based on the observation, the facts obtained in the implementation of science learning in the classroom are as follows. (1) Students appear to be boredom shown by there are some students whose views are unfocused, chatting and playing with a classmate when the subject matter of science is explained by the teacher. (2) Students' ability in scientific process and scientific attitude at the time of trial is very less. (3) Students do not play an active role in constructing their knowledge and are only directed to memorize the subject matter so that most students do not understand the material presented by the teacher. (4) Students rarely have the opportunity to implement the conceptual findings that have been obtained so that the knowledge obtained by students becomes less meaningful. (5) The students' memory of the subject matter of IPA tends to be short and the students' knowledge is not well organized.

Based on the results of document recording of the value of science subjects showed that the results of science subjects science IPA class $\mathrm{V}$ in the first semester of the academic year 2016/2017 is still low. It can be seen from the value of final semester test students on science subjects in cluster II and III of Banjar district still have many under Minimum passing grade criteria. A total of 80 students from 157 students have not reached the minimum passing grade criteria. Meanwhile, if seen from the average grade in each elementary school ranges from 66.9 to 73.3 are in enough categories.

The findings of low learning outcomes of IPA indicate that there is a need to improve the process of science learning. Efforts that can be done by teachers to improve the process of science learning is to use various approaches, strategies, models, media, and methods exactly in accordance with the existing problems. One of the alternatives considered to be able to improve the learning outcomes of IPA is learning with POGIL model. POGIL stands for Process Oriented Guided Inquiry Learning. POGIL learning model is one of inquiry model of inquiry is guided inquiry based on process. Inquiry is a learning process where students explore all available resources to gain understanding [7].

Warsono and Hariyanto [8] stated that POGIL learning applies a method based on student-centered learning and a structure that consistently presents how students learn and achieve their learning outcomes. POGIL model is a learning model based on constructivism theory. As Farrell et al., And Spencer [9] argue that this study is based on scientific discoveries derived from a series of inquiry processes. Hale and Mullen [10] say that the objectives of this teaching design (POGIL) are: (1) to develop content and (2) to develop processorientation skills such as problem solving, critical and analytical thinking, and oral and written communication. The POGIL model activities are built on the framework of the learning cycle, an approach that proves to be effective in science learning (Karplus et al., In Simonson and Shadle, 2013). Barthlow [11], states that the learning cycle consists of three stages, namely exploration, concept discovery, and application. After learning POGIL students will get the concepts in the subject matter. Mind map is one way to organize concepts that have been learned by students.

The mind map is a technique of organizing information obtained into the form of images, symbols, or colors creatively and effectively in order to facilitate the recipient's understanding of information and remember it longer [12]. The mind map is a way to assimilate the concepts that students have learned [13]. In POGIL learning mind maps will be used at the end of learning to review what students already know. This activity can make the knowledge that has been obtained by students to be more structured.

Based on the above description, it is necessary to conduct research with the aim to know the difference of science learning outcomes between groups of students who were taught by POGIL learning model assisted mind map, POGIL learning model, and group of students who were taught by conventional learning in grade V SD students in cluster II and III of Banjar district in academic year 2016/2017.

\section{RESEARCH METHODS}

This research is a quasi experiment and using post test only control group design design. The populations of the study were all students of grade $\mathrm{V}$ of elementary school in cluster II and III of Banjar district in academic year 2016/2017. Samples were taken by random sampling technique. Before determining the sample of the study, the population was tested for equivalence based on the result on final semester test of IPA (science subject) of odd semester by One Way Anava test. Based on equality test conducted, it is known that the value of science learning outcomes of students in the cluster has been equal. Based on the result of the lottery, the sample of this study was the grade V students in SD Negeri 2 Tigawasa as the first experimental group with 28 students, the grade V students in SDN 3 Dencarik as the second experiment group with 14 students and the grade $\mathrm{V}$ students in SD Negeri 3 Tigawasa as a control group with 31 students. The first experimental group followed the POGIL-assisted learning model of mind map, the second experimental group followed the POGIL learning model, and the control group followed the conventional learning. Variables in this study consisted of independent variables of learning model and dependent variable that was the result of science learning.

The data collected in this research was the data of science learning outcomes of grade $\mathrm{V}$ elementary 
school students in cluster II and III of Banjar district in Buleleng regency. Data of science learning result of student in this research was collected by using test method and using one kind of instrument research that was in the form of multiple choice test as much as 30 items. The data collection was analyzed by using descriptive statistical analysis, prerequisite test analysis and hypothesis test using independent $t$ test.

\section{RESULTS AND DISCUSSION}

Measurements were made after the first experimental group was given POGIL learning model assisted with mind map, the second experiment group was given POGIL learning model, and the control group was given conventional learning for seven times meeting with the same teaching materials. Data analysis was done in each class that is experiment class and control class. In the group of students who were studied with POGIL model, the mind map of many students who got the average score of the group (25.25) was $32.14 \%$. While the score below the average of $28.57 \%$ and who got an above average value of $39.29 \%$. In the group of students who were studied with the model POGIL got the average value of the group that was $35.71 \%$. While the score below the average of $35.54 \%$ and who got an above average value of $28.57 \%$. While in the group of students who were taught by conventional learning who got the value around the group average (18.16) that was $32.26 \%$. While the score below the average of $35.48 \%$ and who got an above average value of $32.26 \%$.

After performing descriptive statistical analysis, further prerequisite test was done to test the hypothesis. The prerequisite test was the normality test of data distribution and homogeneity test of variance. The normality test of data distribution was done by Kolmogorov Smirnov statistic. Result of normality test of data distribution of science learning result in first experimental group obtained value $\mathrm{F}=$ 0,099 with significance $=0,200$; in the second experimental group obtained a value of $\mathrm{F}=0.201$ with significance $=0.128$; and in the control group obtained the value of $\mathrm{F}=0.101$ with significance $=$ 0.200. All groups of data obtained a significance value greater than 0.05 so that all data from the learning outcomes of each group IPA (science) normally distributed.

Furthermore, a homogeneity test of experimental group variance and control group was conducted. The homogeneity test of variance was performed using statistical levene. Based on the homogeneity test that has been done on the data obtained from the learning result of IPA Fhitung = 0.393 with significance of 0.676 . Thus, the data variance of science learning outcomes of the group of students who were taught by the POGIL model was assisted by mind map, learned by POGIL model, and the group of students given conventional learning was homogeneous. After obtaining the result of prerequisite test analysis then continued with hypothesis test. Variance analysis was done to know the influence of learning model of POGIL assisted mind map to student learning outcomes of IPA (science).

Based on the hypothesis test, it was found that there was a significant effect of POGIL learning model with the help of mind mapping toward the learning result of IPA ( $F=27,13$ and significance $<0,05)$. The average of science learning outcomes of the group of students who were taught by the learning model of POGIL was assisted by mind mapping of 25.25. Average learning outcomes of science group of students who were taught by POGIL learning model of 24.38; and the average science learning outcomes of the students group that conventional learning was 18.16. Thus, it could be seen that there were significant differences in science learning outcomes between groups of students who were taught by POGIL learning model assisted with mind map, POGIL learning, and group of students who were taught by conventional learning in grade V SD students in cluster II and III of Banjar district in academic year 2016/2017.

POGIL-assisted learning model of mind map in this study showed different effect on science learning outcomes between groups of students who were taught by POGIL model assisted with mind map, group of students who were taught by POGIL model, and group of students who were taught by conventional learning. Based on the results of data analysis, the results of hypothesis testing has successfully rejected $\mathrm{H} 0$ that there was no significant difference in the results of science learning between groups of students who were taught by POGIL learning model assisted mind map, POGIL learning, and group of students who were taught by conventional learning in grade $\mathrm{V}$ elementary students in cluster II and III of Banjar district in academic year 2016/2017. This means that there was a significant difference of science learning outcomes between groups of students who were taught by POGIL learning model with mind map, POGIL learning, and group of students who were taught by conventional learning in grade $\mathrm{V}$ elementary students in cluster II and III of Banjar district in academic year 2016 / 2017.

Descriptively, the learning outcomes of the science group of students who were taught by the POGIL model were supported with mind maps higher than those of students who were taught by POGIL, and groups of students who were taught by conventional learning. The average of science learning outcomes of the group of students who were taught by the learning model of POGIL assisted by mind mapping was 25.25; average learning outcomes of science group of students who were taught by POGIL learning model was 24.38; and average science learning outcomes group of students who were taught by conventional learning was 18.16 . Based on the hypothesis test and descriptive analysis, 
it could be taken information that the learning model of mind mapping assisted with POGIL tends to be superior in determining the results of science learning obtained by students compared to learning models POGIL and conventional learning.

There are several things that can cause the learning outcomes of science group of students who were taught by POGIL model with mind map was higher than the result of science learning group of students who were not learning with POGIL model with mind mapping. POGIL learning model provides great opportunities for students to behave actively involved directly in the learning process. The POGIL model activity builds on the framework of the learning cycle, an approach that proves to be effective in science learning [9].

Hanson [14] stated that the learning cycle in POGIL learning model consists of three stages: exploration, concept invention or formation, and application. In the exploration phase, students would answer various questions to develop student learning outcomes. In the phase of discovering the concept, the teacher as a learning facilitator provides assistance to students to find concepts. Concepts were not given directly, but teachers encourage students to be able to make conclusions and make predictions. In the application phase, students were guided to use the new knowledge they have acquired to solve complex problems. In the application phase students were faced with high-level questions that require analysis to be able to answer them. In the final step of learning, mind maps were used to review what students already know after the investigation. This activity makes the knowledge that was gained through learning POGIL become more structured and organized.

In line with the above opinion, Hanson [14] also stated the advantages of POGIL model are: 1) build their own knowledge based on previous knowledge. 2) Students think creatively in class and laboratory. 3) Draw conclusions by analyzing data, models, or examples by discussing. Barthlow [11] states that the POGIL model can develop process skills in the areas of learning, thinking, and problem solving, involving students to take roles in learning, increasing interaction among students, improving students' attitudes toward knowledge.

Based on the above description, it can be seen that learning by using POGIL model with mind map provides opportunity for students to find out their own answers to the problems given through learning team and guided inquiry activity. In addition, the POGIL model can train thinking skills. Metacognition refers to a person's deep understanding of knowledge that possessed effectively. In the learning process using POGIL model, the teacher only acts as a facilitator or mentor in the learning process which is to provide conducive conditions during the learning process continuity by presenting challenging problems for the students through giving problem which is done in each group,
So, the motivation will appear in students itself to solve it.

After learning POGIL students will get the concepts in the subject matter. Mind map is one way to organize concepts that have been learned by students. The mind map or often referred to as mind mapping is very suitable to be used in inquiry-based learning that is to plan investigation and review what students have known [15]. Creating mind maps is one way to assimilate the concepts that have been learned by students [13]. In POGIL learning the mind map will be used at the end of the lesson to review what students already know after the investigation. This activity will make the knowledge gained through POGIL learning become more structured and organized.

POGIL (Process Oriented Guided Inquiry Learning) is the learning based on science discovery obtained by a series of inquiry process. The process of applying POGIL asked the students to study in groups consisting of 3-4 students. Each individual in the small group that has been formed has their respective roles as: (1) the leader of discussion and group work, (2) the reflector or evaluation for the enhancement of group cooperation, (3) As the note taker of all group work, (4) and the last one as a spokesperson when reporting the work of the group to the front of the class. Besides applying cooperative learning or grouping, the POGIL (Process Oriented Guided Inquiry Learning) model is essentially a guided inquiry activity for developing knowledge, questions to improve critical thinking and analytical thinking, problem solving, reporting, metacognition, and individual responsibility. These seven components are used to develop science process skills and control of disciplinary [14].

Based on the observation, in the group of applying POGIL (Process Oriented Guided Inquiry Learning) learning model, students tend to follow active learning, teamwork and guided inquiry activities so that students can find a fact, concept, principle or theory. In POGIL (Process Oriented Guided Inquiry Learning) model the students work together in teams and their tendency to participate in the class, so that learning is not boring and encouraging students to compete competitively between groups / teams. In this classroom atmosphere can distinguishes the classroom atmosphere and conduciveness of the group that is not taught by the POGIL (Process Oriented Guided Inquiry Learning) model. In the group of students who are taught by POGIL (Process Oriented Guided Inquiry Learning) tends the group of students in conventional learning to be passive, process of learning is monotonous and less stimulate student to competent in learning. The subject matter received by the students from the teacher is only a memory or memorization, which causes the weakness of the learning outcomes of the science.

The result of descriptive statistical analysis and hypothesis test have shown that the result of 
science learning of group of students who were taught by POGIL model assisted mind map better than group of student who were not taught by POGIL model assisted with mind map. This is in line with the results of research conducted by Lestari [16] in grade $\mathrm{V}$ elementary students in cluster I in Gianyar district stated that there was a significant difference of science learning outcomes between the students who were taught by POGIL model and students who were taught by conventional model. The average score of learning outcomes in the group of students who were studied using the POGIL model was 23.36 while the mean score of learning outcomes in the group of students who were taught using the conventional model was 17.23.

In addition, the results of research conducted by Sari, et al [17] in the class XI students in SMA Negeri 1 Kartasura stated that there were some differences in student learning outcomes who were taught by using POGIL with the students who were taught with POGIL and mind mapping. The average score of cognitive learning outcomes of students who were taught by POGIL model with mind mapping higher than students who were taught by POGIL model without mind mapping. The average score of cognitive learning outcomes of students who were studied with POGIL model with mind mapping was 81.6 while students who were taught by POGIL model without mind mapping was 73.2.

\section{CONCLUSION}

Based on the result of research, it can be concluded that there were significant differences of science learning outcomes between groups of students who were taught by POGIL learning model assisted with mind map, group of students who were taught by POGIL learning model, and group of students who were taught by conventional learning in grade V elementary students in cluster II and III of Banjar district in academic year 2016/2017. Descriptively, the learning outcomes of the science group of students who were taught by the POGIL model were supported with mind maps higher than the group of students who were taught by POGIL, and groups of students who were taught by conventional learning. The average score of science learning outcomes of the group of students who were taught by the learning model of POGIL assisted with mind mapping was 25.25; average learning outcomes of science group of students who were taught by POGIL learning model was 24.38; and the average science learning outcomes of the students group who were taught by conventional learning was 18.16.

Suggestions that can be submitted based on the research that has been done by the researcher was the teachers were suggested to apply POGIL learning model with mind map in order to improve the quality of learning in class and develop student science learning outcomes. This is because in the POGIL learning model with mind map will help students in solving problems with discovery procedures in science as well as get interesting notes that help students more easily remember and understand the material being studied. Teachers should habituate the students in making mind maps and ask them not only limited to science subjects but also on other subjects. In addition, teachers should often form group of discussion in every subjects, so that learners are accustomed to solve problems and questions related to the material through discussion with the group.

The students are advised to practice in creating mind maps that are used as a medium to facilitate students in discovering the concept of science independently, actively and creatively in order to improve the ability of conceptual understanding so that it will have implications on the achievement of optimal learning outcomes. This research is limited to discuss about the nature of light and rock, involving samples limited to one cluster, and measuring one variable that is the result of science learning. To other researchers, it is suggested to conduct further research about POGIL learning model with mind map in science (IPA) and other subject matter. In the other science materials involves larger samples as an example in one district or regency and involving other variables to obtain more optimal results.

\section{REFERENCES}

[1] Wiratma, I.G.L. "Politik Pendidikan dalam Pengembangan Kesadaran Kritis dan Jati Diri”. Jurnal IKA. Volume 8. Nomor 2. (Halaman 107-122). 2010.

[2] Kemdikbud. "Pendidikan Indonesia Gawat Darurat". Tersedia pada http://www.kemdikbud.go.id/kemdikbud/node/3 571 (diakses tanggal 30 Desember 2016).

[3] Kemdikbud. "Peringkat dan Capaian PISA Indonesia Mengalami Peningkatan". Tersedia pada:http://www.kemdikbud.go.id/main/blog/20

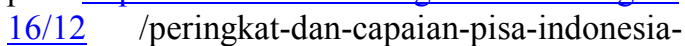
mengalami-peningkatan (diakses tanggal 30 Desember 2016).

[4] Susanto, Ahmad. "Teori Belajar dan Pembelajaran di Sekolah Dasar". Cetakan Ke-2. Jakarta: Prenadamedia Group. 2014.

[5] Santyasa, I. W. "Belajar dan Pembelajaran". Singaraja: IKIP Undiksha. 2005.

[6] Trianto. "Model-model Pembelajaran Inovatif Berorientasi Konstruktivistik". Cetakan Ke-1. Jakarta: Prestasi Pustaka.2007.

[7] Brickman, Peggy. "Effect of Inquiry-based Learning on Students' Science Literacy Skills and Confidence". International Journal Scholarship of Teaching and Learning. Volume 3. Nomor 2. 2009. 
[8] Warsono dan Hariyanto. "Pembelajaran Aktif Teori dan Asesmen". Cetakan Ke-3. Bandung: PT Remaja Rosdakarya. 2014.

[9] Simonson, S. R. dan Susan E. S. "Implementing POGIL in Undergraduate Biomechanics: Lessons Learned by A Novice". Journal of STEM Education. Volume 14 (Halaman 56 63). 2013.

[10] Hale, Dena dan Linda Greef Mullen. "Designing Process-Oriented Guided-Inquiry Activities: A New Innovation for Marketing Classes". Marketing Education Review. Volume 19. Nomor 1. (Halaman 74-80). 2009.

[11] Barthlow, Michele J. dan Scott B. Watson. "The Effectiveness of Process-Oriented Guided Inquiry Learning to Reduce Alternatif Conceptions in Secondary Chemistry". School science and Mathematics. Volume 114. Nomor 5. (Halaman 246-255). 2011.

[12] Buzan, Tony. "Buku Pintar Mind Map untuk Anak", Jakarta: PT Gramedia Pustaka Utama. 2007.
[13] Wardani, T.Y.P. "Pengaruh Model Heuristik Vee dengan Peta Pikiran terhadap Hasil Belajar IPA Siswa Kelas V SD". E-journal Mimbar PGSD Universitas Pendidikan Ganesha. Volume 3. Nomor 1. 2015

[14] Hanson, David M. "Instructor's Guide to Process-Oriented Guided-Inquiry Learning". Lisle, IL: Pacific Crest. 2006.

[15] Anam, Khoirul, "Pembelajaran Berbasis Inkuiri Metode dan Aplikasi”, Yogyakarta: Pustaka Pelajar, 2016.

[16] Lestari, Desak Putu Sri. "Pengaruh Model POGIL dan Minat Belajar Terhadap Hasil Belajar IPA pada Siswa Kelas V SD”. E-journal Mimbar PGSD Universitas Pendidikan Ganesha. Volume 4. Nomor 1. 2016.

[17] Sari, S. D. C. dkk. "Pengaruh POGIL (Process Oriented Guided Inquiry Learning) Disertai Mind Mapping terhadap Hasil Belajar Siswa pada Materi Asam Basa". Program Studi Biologi, Fakultas Biologi, Universitas Kristen Satya Wacana. 2015. 